\title{
A proof of concept study of Infliximab for the treatment of HTLV-1-associated myelopathy
}

\author{
Fabiola Martin ${ }^{1}$, Hannah Castro ${ }^{2}$, Carolyn Gabriel ${ }^{3}$, Adine Adonis ${ }^{4}$, Alexandra Fedina ${ }^{4}$, Linda Harrison², \\ Liz Brodnicki ${ }^{2}$, Maria A Demontis ${ }^{5}$, Abdel G Babiker ${ }^{2}$, Jonathan N Weber ${ }^{4,5}$, Charles RM Bangham ${ }^{5}$, \\ Graham P Taylor ${ }^{4,5^{*}}$
}

From 16th International Conference on Human Retroviruses: HTLV and Related Viruses Montreal, Canada. 26-30 June 2013

\section{Background}

Disease modifying treatment options for patients with HAM are limited. Most studies have included all patients regardless of duration, disability or disease activity. The Medical Research Council UK funded a series of proof of concept studies for patients with early (50\% deterioration during preceding 3 months). The results of the first study of ciclosporin have been published. The second study, of the anti-TNF monoclonal antibody Infliximab, is presented.

\section{Study design}

Open-label, clinical endpoint study of Infliximab $3 \mathrm{mg} / \mathrm{kg}$ infused intravenously at weeks 0,2 and 8 and then every 8 weeks until and including week 40 of the study. Primary endpoints were time to and incidence of clinical failure.

\section{Results}

The study was terminated early for futility. Three patients were recruited to and completed the study. Patient \#1 developed a rash and headache after the 2 nd infusion. This was considered to be immune complex mediated. Patient \#2 experienced hypersensitivity reaction with profound hypotension during the 4th infusion (week 16). In both cases treatment was discontinued. Patient \#3 completed all 7 infusions without adverse effect. Reduced spasticity was observed in all 3 patients during ontreatment period. Patient \#1 was unable to stand throughout the study. $10 \mathrm{~m}$ timed walk improved in Patient \#2 but deteriorated in \#3. No trend was observed

\footnotetext{
* Correspondence: g.p.taylor@imperial.ac.uk

${ }^{4}$ National Centre for Human Retrovirology, St Mary's Hospital, London, UK
} Full list of author information is available at the end of the article in pain scores, $\beta 2 \mathrm{M}$ or HTLV-1 viral load in blood and CSF.

\section{Conclusion}

High severe adverse event rate with Infliximab therapy was observed. Future studies should co-administer with methotrexate as per the treatment of rheumatoid arthritis.

\section{Authors' details \\ ${ }^{1}$ Centre for Immunology and Infection, Department of Biology, Hull and York Medical School, University of York, York, UK. ' ${ }^{2}$ Medical Research Council, Clinical Trials Unit, London, UK. ${ }^{3}$ Department of Neurology, St Mary's Hospital, London, UK. ${ }^{4}$ National Centre for Human Retrovirology, St Mary's Hospital, London, UK. ${ }^{5}$ Section of Infectious Diseases, Faculty of Medicine, Imperial College, UK.}

Published: 7 January 2014

doi:10.1186/1742-4690-11-S1-P31

Cite this article as: Martin et al:: A proof of concept study of Infliximab for the treatment of HTLV-1-associated myelopathy. Retrovirology 2014 11(Suppl 1):P31.

Submit your next manuscript to BioMed Central and take full advantage of:

- Convenient online submission

- Thorough peer review

- No space constraints or color figure charges

- Immediate publication on acceptance

- Inclusion in PubMed, CAS, Scopus and Google Scholar

- Research which is freely available for redistribution

Submit your manuscript at www.biomedcentral.com/submit
() Biomed Central 